\title{
Evolution and Conservation of Predicted Inclusion Membrane Proteins in Chlamydiae
}

\author{
Erika I. Lutter, ${ }^{1}$ Craig Martens, ${ }^{2}$ and Ted Hackstadt ${ }^{1}$ \\ ${ }^{1}$ Host-Parasite Interactions Section, Laboratory of Intracellular Parasites, Rocky Mountain Laboratories, National Institute of Allergy \\ and Infectious Diseases, National Institutes of Health, Hamilton, MT 59840, USA \\ ${ }^{2}$ Research Technologies Branch, Rocky Mountain Laboratories, National Institute of Allergy and Infectious Diseases, National Institutes \\ of Health, Hamilton, MT 59840, USA \\ Correspondence should be addressed to Ted Hackstadt, ted_hackstadt@nih.gov
}

Received 21 September 2011; Accepted 30 November 2011

Academic Editor: Shen Liang Chen

Copyright () 2012 Erika I. Lutter et al. This is an open access article distributed under the Creative Commons Attribution License, which permits unrestricted use, distribution, and reproduction in any medium, provided the original work is properly cited.

Chlamydia spp. are obligate intracellular pathogens that replicate within a vacuole termed the inclusion. Chlamydiae extensively modify the inclusion membrane via the insertion of chlamydial inclusion membrane proteins (Incs) which decorate the cytosolic face of the inclusion. We have assessed the overall relatedness and phylogeny of Incs in order to identify potential evolutionary trends. Despite a high degree of conservation among Incs within C. trachomatis serovars, phylogenetic analysis showed that some Incs cluster according to clinical groupings suggesting that certain Incs may contribute to tissue tropism. Bioinformatic predictions identified Incs in five chlamydial species: 55 in C. trachomatis, 68 in C. felis, 92 in C. pneumoniae, 79 in C. caviae, and 54 in C. muridarum. Inc homologues were compared between chlamydial species and 23 core Incs were identified as shared among all species. Genomic expansion of Incs was identified in C. pneumoniae, C. caviae, and C. felis but not C. trachomatis or C. muridarum.

\section{Introduction}

Chlamydiae are obligate intracellular pathogens that cause a variety of human and veterinary infections. Chlamydia trachomatis is the leading cause of preventable blindness worldwide and the most common bacterial sexually transmitted infection [1]. The species is comprised of 15 serovars that are associated with a wide spectrum of disease states including endemic trachoma (serotypes A to C), sexually transmitted infections (serotypes $\mathrm{D}$ to $\mathrm{K}$ ), and a highly invasive granulomatous disease, lymphogranuloma venereum (LGV; serotypes L1 to L3) [1]. C. pneumoniae is a common cause of community acquired pneumonia and bronchitis [2] and has been linked to a spectrum of chronic diseases including atherosclerotic cardiovascular disease [3]. C. felis is a causative agent of feline chlamydiosis [4]. C. caviae and C. muridarum cause infections in guinea pigs and mice, respectively [5].

Despite the differences in host tropism and disease, all Chlamydia spp. share several unique properties. Chlamydiae undergo a biphasic developmental cycle consisting of metabolically inactive infectious elementary bodies (EBs) and metabolically active noninfectious, reticulate bodies (RBs). Within the host cell, chlamydiae reside in a parasitophorous vacuole called the inclusion whose interactions with the host cell are unlike any other intracellular pathogen in that it is nonfusogenic with the endocytic pathway but intercepts exocytic vesicular traffic from the Golgi apparatus [6-8]. The inclusion membrane is at the interface between the pathogen and the host cell thus is situated to regulate exchange between the inclusion lumen and host cytosol $[6,9-13]$. The inclusion membrane is heavily modified by the insertion of type III secreted chlamydial effector proteins shortly after the initiation of chlamydial protein synthesis. These inclusion membrane proteins, or Incs, are localized to the inclusion membrane and exposed to the host cytosol $[14,15]$.

Much effort has been placed into the identification of Incs in chlamydiae through in silico predictions. While Incs share little sequence similarity to each other or known proteins in sequence databases thereby limiting speculation as to their function, they do however share a common secondary structural feature of a bilobed hydrophobic domain $[16,17]$. The bilobed hydrophobic domain is a large hydrophobic 
region of 40 or more amino acids and may contain some centrally located hydrophilic residues to produce a characteristic bilobed hydropathy plot $[16,18]$. This motif is largely specific to chlamydiae since comparative genomics only identified a few Inc-like open reading frames in other organisms [18]. This feature has been used to predict Inc proteins across different chlamydial species generating lists of putative proteins numbering from 36 to 59 for $C$. trachomatis [16, 18-21], 90 to 107 for C. pneumoniae [18, 19], 86 for C. caviae [19], 59 for C. muridarum [19], and 63 to 78 for C. felis $[19,22]$. Despite the number of interactions with the host cell that are common throughout the genus and the potential for Incs to define interactions with the host cell at the interface of the inclusion and cytoplasm, there appears to be little conservation of Incs between species.

Here we examine evolutionary relationships of Incs within C. trachomatis and between species in an effort to identify those Incs which might regulate conserved functions. The results demonstrate that overall there is a high level of conservation of Incs among C. trachomatis serovars at both the nucleotide and amino acid levels. Despite this overall high degree of similarity, certain Incs within C. trachomatis appeared to be evolving according to tissue tropism. A comparative genomics approach was used to identify Inc homologues shared or unique to C. trachomatis, C. muridarum, C. felis, C. caviae, and C. pneumoniae. Overall, there was little sequence conservation between distant homologues despite conservation in the hydrophobic nature and bilobed hydrophobic domains. Cross-genome comparisons identified a number of unique Incs to each species, shared Incs between paired species, and a core subset of Incs common to all species.

\section{Materials and Methods}

2.1. Inclusion Membrane Protein Prediction. Inclusion membrane proteins were predicted in C. trachomatis $\mathrm{L} 2 / 434 / \mathrm{Bu}$ (NC_010287.1), C. felis Fe/C-56 (NC_007899.1), C. muridarum Nigg (NC_002620.2), C. caviae GPIC (NC_003361.3) and C. pneumoniae AR39 (NC_002179.2). Kyte and Doolittle hydropathy plots [23] were generated for all proteins in the above genomes. The plots were scanned for the presence of 2 hydropathy peaks within 40 amino acids of each other or for the presence of one very large peak of greater than 40 amino acids. Added weight was given to proteins that were predicted to contain a transmembrane helix using TMHMM [24].

2.2. Identification of Inc Homologues. For analysis of Incs between C. trachomatis strains, corresponding Incs were used from the following strains: A/Har-13 (NC_007429.1), B /Jali20/OT (NC_012686.1), B/TZ1A828/OT (NC_012687.1), DLC (CP002054), D-EC (CP002052), D/UW-3/CX (NC_000 117.1), E/11023 (CP001890), E/150 (CP001886), E/Sweden2 (FN652779), G/9301 (CP001930), G/9768 (CP001887), G/11074 (CP001889), G/11222 (CP001888), and L2b/UCH1/proctitis (NC_010280.1). The resulting predicted Incs were then cross referenced with the other genomes using a PSIBLAST to identify homologues [25].
2.3. Phylogenetic Distance and Genetic Divergence. Nucleic acid sequence alignments for predicted Incs from different strains were generated using ClustalW [26]. Phylogenetic analysis of Incs was performed on nucleotide sequences using the Neighbor-Joining method [27] of MEGA4 [28]. Bootstrap consensus trees were inferred from 1000 replicates with the percentage of replicate trees in which the associated taxa clustered together in the bootstrap test displayed on the corresponding branches [29]. Estimates of evolutionary divergence were calculated using MEGA4. Results are based on the number of nucleic acid base pair substitutions per site on a pairwise analysis between all sequence pairs available for each inc and pmp using the Maximum Composite Likelihood Method $[28,30]$. The mean genetic distance and pairwise comparisons were based on the number of nucleotide differences that included both transitions and transversions with gaps excluded. Additionally, the Nei-Gojobori Method [31] was performed comparing nonsynonymous $\left(d_{N}\right)$ and synonymous $\left(d_{S}\right)$ substitutions.

\section{Results and Discussion}

3.1. Genetic Divergence of Incs between C. trachomatis Strains. To identify putative Incs within $C$. trachomatis $\mathrm{L} 2 / 434 / \mathrm{Bu}$, a computational approach was designed to identify proteins that contained a hydrophobic domain of greater than 40 amino acids or two transmembrane domains of 20-30 amino acids separated by a small loop region $[16,19]$. Each protein identified was analyzed using Kyte and Doolittle plot analysis to verify the presence of the characteristic bilobed hydrophobic domain [23]. A list of predicted Inc proteins is provided in Table 1 . The Incs predicted by our computational method provided assemblages similar to those previously compiled $[16,19,20]$. Corresponding Incs from other $C$. trachomatis strains where complete genomes were available were downloaded and analyzed for evolutionary distance using MEGA4 (Figure 1). As an internal control for comparative purposes, the polymorphic outer membrane proteins ( $p m p A-I$ ) were also analyzed using nucleotide sequences obtained from the available genomes. The mean genetic distances obtained for C. trachomatis Incs ranged from 0.001 (CT789) to 0.017 (CT116) with Incs CT115, CT116, CT223, and CT229 being the most divergent. Many of the Incs appeared genetically conserved in that they exhibited very little divergence (Figure 1). The genetic divergence seen among the pmps was similar to what was previously described. PmpE, $p m p F$, and $p m p H$ contained the most polymorphisms (mean genetic distances of $0.025,0.065$, and 0.014 resp.) [32]. These data suggest that despite being highly conserved, some Incs may be evolving at different rates, equivalent to the more divergent of the pmps.

Although distinct diseases and tissue tropisms are associated with different $C$. trachomatis serovars, the genomes examined to date exhibit a high degree of synteny and greater than $99 \%$ sequence identity [33-35]. The overall conservation seen between genomes indicates that there are relatively few loci involved in tissue tropism or that small polymorphisms in certain genes may greatly impact 
TABLE 1: Open reading frames with predicted Inc-like domains ${ }^{\mathrm{a}}$.

\begin{tabular}{|c|c|c|c|c|}
\hline C. trachomatis & C. muridarum & C. caviae & C. felis & C. pneumoniae \\
\hline$-^{\mathrm{b}}$ & - & CCA00222 & CF0784 & СР0230 \\
\hline - & TC0328 & CCA00221 & CF0785 & СР0229 \\
\hline - & - & CCA00353 & - & СР0314 \\
\hline СТ005 & TC0273 & CCA00290 & CF0713 & $\mathrm{CP} 0310$ \\
\hline СТ006 & TC0274 & CCA00291 & CF0711 & СР0311 \\
\hline- & - & CCA00318 & - & - \\
\hline СТ036 & TC0306 & CCA00647 & - & СР0642 \\
\hline - & - & CCA00645 & - & - \\
\hline - & - & CCA00361 & CF0646 & СР0322 \\
\hline - & - & - & CF0611 & - \\
\hline - & - & CCA00397 & CF0610 & - \\
\hline СТ058 & TC0328 & CCA00426/425/398/221 & CF0609 & СР0387/388/390/667* \\
\hline СТ079 & TC0351 & CCA00449 & - & СР0424 \\
\hline CT101 & - & CCA00470 & CF0537 & СР0446 \\
\hline $\mathrm{CT} 115^{\dagger}$ & TC0391 & - & - & - \\
\hline CT115 & - & CCA00622 & $\mathrm{CF} 0382^{\dagger}$ & - \\
\hline CT116 & TC0392 & - & - & - \\
\hline CT117 & TC0393 & - & - & - \\
\hline CT118 & TC0394 & - & - & - \\
\hline- & - & CCA00636/633/634/639 & CF0574 & $\mathrm{CP} 0401^{\dagger}$ \\
\hline- & - & CCA00530 & CF0479/369 & СР0404/407 \\
\hline- & - & CCA00434 & CF0574 & СР0405/404 \\
\hline $\mathrm{CT}_{119^{\dagger}}$ & TC0396 & CCA00550 & CF0458 & - \\
\hline- & - & CCA00550 & - & $\mathrm{CP} 0581^{\dagger}$ \\
\hline CT134 & TC0411 & CCA00537 & CF0471 & СР0520/519 \\
\hline CT135 & $\mathrm{TC} 412^{\dagger}$ & CCA00538 & - & СР0522* \\
\hline CT135 & TC0412 & CCA00538 ${ }^{\dagger}$ & CF0470 & CP0521*/522* \\
\hline CT147 & TC0424 & CCA00616 & CF0388 & СР0623 \\
\hline- & - & CCA00621 & CF0383 & СР0627 \\
\hline - & - & CCA00620 & CF0384 & - \\
\hline - & - & CCA00619 & CF0385 & СР0626 \\
\hline CT164 & - & - & - & - \\
\hline- & - & CCA00557 & CF0449/450/451 & $\mathrm{CP} 0730^{\dagger}$ \\
\hline \multirow[t]{2}{*}{ - } & - & CCA00557 ${ }^{\dagger}$ & CF0449/450/451 & - \\
\hline & & CCA00576 & CF0425 & СР0595 \\
\hline CT179 & TC0451 & CCA00591 & CF0412 & СР0534 \\
\hline CT192 & TC0464 & - & - & - \\
\hline CT195 & TC0468 & CCA00494 & CF0513 & СР0470 \\
\hline- & - & CCA00514 & CF0493 & СР0493/495 \\
\hline CT196 & TC0469 & - & - & - \\
\hline СТ214 & TC0486 & CCA00500 & CF0508 & - \\
\hline- & - & - & CF0504 & - \\
\hline - & - & CCA00513 & - & $\mathrm{CP} 0707^{\dagger}$ \\
\hline- & - & ${\mathrm{CCA} 00513^{\dagger}}^{+}$ & $\mathrm{CF} 0494^{\dagger}$ & СР0730 \\
\hline СТ222 & - & - & - & - \\
\hline СТ223 & TC0495 & - & - & СР0709 \\
\hline СТ224 & - & - & - & - \\
\hline СТ225 & - & - & - & - \\
\hline- & TC0496 & - & - & СР0390 \\
\hline
\end{tabular}


Table 1: Continued.

\begin{tabular}{|c|c|c|c|c|}
\hline C. trachomatis & C. muridarum & C. caviae & C. felis & C. pneumoniae \\
\hline CT226 & TC0497 & - & - & - \\
\hline CT227 & TC0498 & - & - & - \\
\hline CT228 & TC0499' & CCA00513 & - & - \\
\hline СТ229 & TC0500 & - & - & - \\
\hline CT232 & TC0503 & CCA00491 & CF0516 & СР0467 \\
\hline CT233 & TC0504 & CCA00490 & CF0517 & СР0466 \\
\hline CT244* & TC0515 & - & CF0528* & СР0455* \\
\hline СТ249 & TC0520 & - & - & - \\
\hline- & - & CCA00474 & CF0533 & - \\
\hline - & - & CCA00497 & - & СР0473 \\
\hline- & - & CCA00586* & CF0422* & СР0481 \\
\hline- & - & CCA00513 & - & СР0539 \\
\hline - & - & CCA00582* & CF0418 & СР0581 \\
\hline - & - & CCA00576 & CF0425 & СР0595 \\
\hline - & - & CCA00430 & - & - \\
\hline - & - & CCA00424 & CF0583 & СР0649 \\
\hline - & - & CCA00398 & CF0609 & СР0387 \\
\hline - & - & CCA00397 & CF0610 & - \\
\hline- & - & CCA00352 & - & СР0313 \\
\hline CT288 & TC0561 & CCA00351 & CF0654 & $\mathrm{CP} 0709^{\dagger}$ \\
\hline- & TC0573 & - & - & - \\
\hline CT300 & TC0574 & - & - & - \\
\hline СТ324 & TC0598 & CCA00700 & CF0311 & СР0703 \\
\hline СТ345 & TC0624 & - & - & - \\
\hline CT357 & TC0636 & - & - & - \\
\hline СТ358 & TC0637 & - & CF0218 & - \\
\hline - & - & CCA00361 & CF0646 & СР0322 \\
\hline- & - & CCA00360 & CF0647 & СР0321 \\
\hline - & - & CCA00334/00339 & CF667/668/669 & - \\
\hline - & - & CCA00325 & CF0677/678 & СР0742 \\
\hline - & - & CCA00318 & CF0685 & - \\
\hline CT365 & TC0644 & CCA00269 & CF0739 & СР0280 \\
\hline CT383 & TC0662 & CCA00263 & CF0745 & СР0274 \\
\hline - & - & CCA00156 & CF0851 & СР0825/163 \\
\hline CT440 & TC0724 & CCA00188 & CF0818 & СР0198 \\
\hline CT442 & TC0726 & CCA00186 & - & СР0196 \\
\hline CT449 & TC0734 & CCA00177 & CF0830 & СР0185 \\
\hline CT449 ${ }^{\dagger}$ & TC0734 & - & - & СР0185 \\
\hline CT483 & TC0770 & CCA00139 & CF0867 & СР0146 \\
\hline CT484 & TC0771 & CCA00138 & CF0868 & СР0145 \\
\hline - & - & CCA00156 & CF0851 & СР0163 \\
\hline - & - & - & CF0048 & - \\
\hline CT565 & TC0854 & CCA00941 & CF0073 & CP1049 \\
\hline CT616* & TC0906* & CCA01002 & CF0010 & CP1117 \\
\hline CT618 & TC0908 & CCA01004 & CF0008 & CP1119 \\
\hline CT642 & TC0010 & CCA00987 & CF0026 & CP1102 \\
\hline - & TC0011 & - & - & - \\
\hline CT728 & TC0101 & CСA00898 & CF0116 & CP1000 \\
\hline - & - & - & CF0128 & - \\
\hline
\end{tabular}


Table 1: Continued.

\begin{tabular}{|c|c|c|c|c|}
\hline C. trachomatis & C. muridarum & C. caviae & C. felis & C. pneumoniae \\
\hline CT788 & TC0171 & CCA00832 & CF0182 & СР0923 \\
\hline CT789 & - & - & - & - \\
\hline CT813 & TC0199 & - & - & - \\
\hline - & - & CCA00801 & CF0215 & - \\
\hline - & - & CCA00800 & CF0216 & - \\
\hline - & - & CCA00799 & CF0217 & - \\
\hline - & - & CCA00797 & CF0218 & - \\
\hline- & & CCA00795 & CF0219 & - \\
\hline- & - & CCA00794 & CF0220 & - \\
\hline- & - & CCA00793 & - & - \\
\hline СТ819 & TC0206 & CCA00786 & CF0227 & СР0890* \\
\hline СТ846 & TC0234 & CCA00758* & CF0256 & СР0850* \\
\hline CT850 & TC0239 & CCA00753 & CF0261 & СР0845 \\
\hline- & - & CCA00733 & CF0283 & СР0823 \\
\hline - & - & CCA00708 & - & - \\
\hline - & - & CCA00702 & - & - \\
\hline - & - & - & - & СР0236 \\
\hline - & - & - & - & СР0381 \\
\hline - & - & - & - & СР0385 \\
\hline - & - & - & - & СР0386 \\
\hline - & - & - & - & СР0391 \\
\hline - & - & - & - & СР0392 \\
\hline - & - & - & - & СР0396 \\
\hline - & - & - & - & СР0450 \\
\hline - & - & - & - & СР0474 \\
\hline- & - & - & - & СР0544 \\
\hline - & - & - & - & СР0547 \\
\hline - & - & - & - & СР0549 \\
\hline - & - & - & - & СР0550 \\
\hline - & - & - & - & СР0551 \\
\hline - & - & - & - & СР0553 \\
\hline- & - & - & - & СР0554 \\
\hline- & - & - & - & СР0597 \\
\hline - & - & - & - & СР0602 \\
\hline - & - & - & - & СР0605 \\
\hline - & - & - & - & СР0607 \\
\hline - & - & CCA0062* & - & СР0627 \\
\hline - & - & - & - & СР0640 \\
\hline - & - & - & - & СР0641 \\
\hline- & - & - & - & СР0646 \\
\hline - & - & CCA00513 & - & СР0649/797 \\
\hline - & - & CCA00674 & CF0337 & СР0675 \\
\hline - & - & - & - & СР0703 \\
\hline - & - & - & - & СР0733 \\
\hline - & - & - & - & СР0750 \\
\hline- & - & - & - & СР0763 \\
\hline- & - & - & - & СР0728/764/766/769 \\
\hline - & - & - & - & СР0795 \\
\hline
\end{tabular}


TABle 1: Continued.

\begin{tabular}{lcccc}
\hline C. trachomatis & C. muridarum & C. caviae & C. felis & \\
\hline- & - & - & - & C. pneumoniae \\
- & - & - & - & CP0801 \\
\hline
\end{tabular}

${ }^{a}$ Data from Incs identified here and in [16, 18-21].

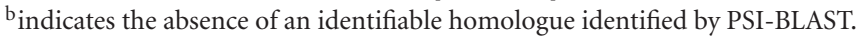

c* indicates that a homologue lacks the characteristic bilobed hydrophobic domain when analyzed with Kyte and Doolittle plots

$\mathrm{d} \dagger$ indicates Inc used in PSI-BLAST.

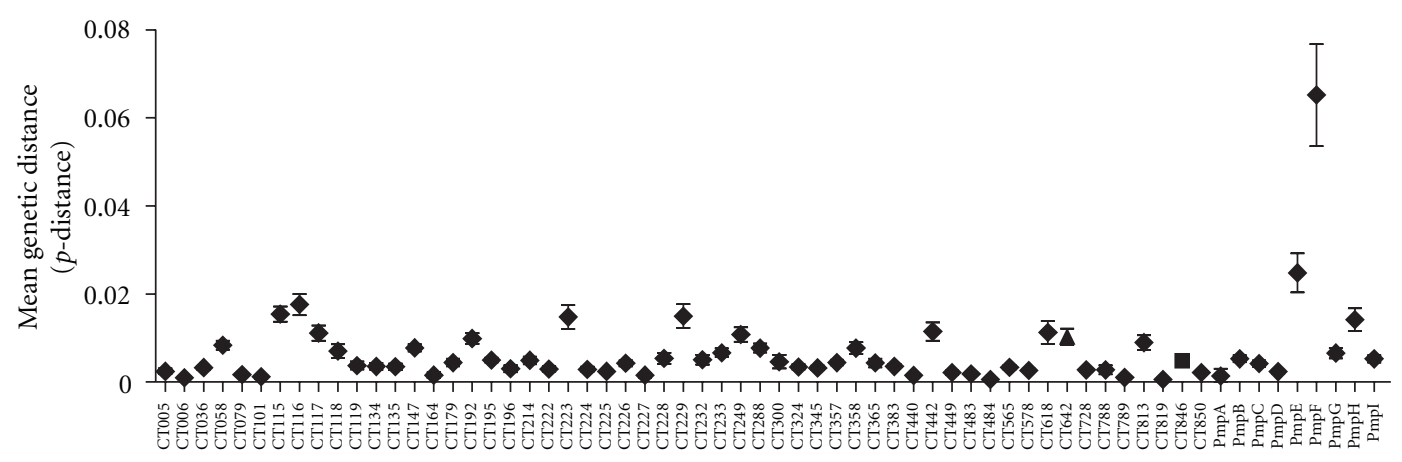

FIGURE 1: Genetic divergence of incs and pmps within C. trachomatis. Mean genetic distance within each predicted inc and pmp genes based on the average $p$-distance was determined from a pairwise comparison between all possible sequences for the same gene. Error bars represent mean with $95 \%$ confidence limit.

the infection process between serovars. Currently, there are few genetic loci that have been linked to clinical phenotype or tissue tropism within $C$. trachomatis. These include members of the Pmps, $p m p B, p m p C, p m p F, p m p G, p m p H$ and $p m p I$ $[32,36], \operatorname{tar} P[37], \operatorname{tox}[38,39], \operatorname{trp} A B[40-42]$, and $h c t B$ $[43,44]$. Here we observed an overall conservation of Incs within different strains of $C$. trachomatis although four Incs (CT115, CT116, CT223, and CT229) appeared to be more divergent than others.

3.2. Phylogenetic Analysis of Incs within C. trachomatis. The variations in genetic divergence seen within predicted Incs of $C$. trachomatis suggested that certain Incs may be under different selective evolutionary pressures. Phylogenetic reconstructions of unrooted trees were performed for each Inc using existing genome sequences from all available serovars. The most divergent Incs, CT115, CT116, CT223, and CT229, exhibited clustering into clinical groupings with CT116 showing a separate clade for LGV strains while CT115, CT223, and CT229 exhibited separate clusters for genital, ocular, and LGV strains (Figures 2(a) and 2(b)). Incs CT214, CT383, CT618, and CT195 also demonstrated phylogenetic clustering according to clinical groupings although they showed less divergence based on genetic distance than Incs CT115, CT116, CT223, and CT229 (Figure 1). It was also possible to identify Incs that displayed partial clustering according to clinical groupings in that there were either separate clusters identified for ocular isolates or LGV isolates but not both. The most phylogenetically divergent clinical cluster was the LGV isolates. Separate LGV clusters could be identified for 35 Incs (Table 2, Figure 2(c)). Separate ocular clusters were identified for six Incs (Table 2, Figure 2(d)).
TABLE 2: Phylogenetic clustering of Incs in C. trachomatis.

\begin{tabular}{|c|c|}
\hline $\begin{array}{l}\text { Ocular, genital, and } \\
\text { LGV }\end{array}$ & $\begin{array}{l}\text { CT115, CT223, CT214, CT229, СТ383, } \\
\text { CT618, CT195 }\end{array}$ \\
\hline LGV specific & 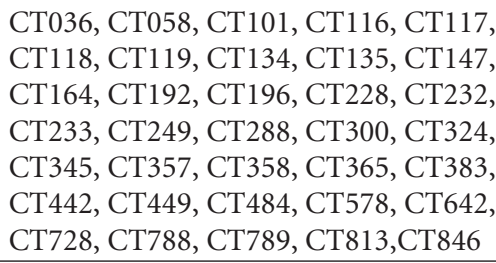 \\
\hline Ocular specific & $\begin{array}{l}\text { CT224, CT225, СТ226, СТ383, СТ846, } \\
\text { CT850 }\end{array}$ \\
\hline $\begin{array}{l}\text { No correlation with } \\
\text { disease }\end{array}$ & $\begin{array}{l}\text { CT005, СT006, СT079, СТ227, СТ440, } \\
\text { CT565 }\end{array}$ \\
\hline $\begin{array}{l}\text { Serovar E specific } \\
\text { clades }\end{array}$ & $\begin{array}{l}\text { CT058, CT116, CT117, CT192, СТ233, } \\
\text { CT249, CT288, CT324, СT357, СТ358, } \\
\text { CT365, CT383, CT442, CT483, CT578, } \\
\text { CT642, CT846, CT850 }\end{array}$ \\
\hline
\end{tabular}

Another trend that was evident was the separate clustering of serovar $\mathrm{E}$ isolates forming a separate clade from the ocular, LGV, and the other urogenital isolates. Finally, there were Incs that did not appear to segregate according to clinical disease (Table 2).

The differences in phylogenetic clustering of Incs suggest that certain Incs may be evolving at different rates than others. Most of the Incs exhibited some clustering according to disease groupings. Seven Incs produced separate clusters for urogenital, LGV, and ocular strains, 35 Incs produced separate LGV clades, and 6 Incs produced separate ocular 


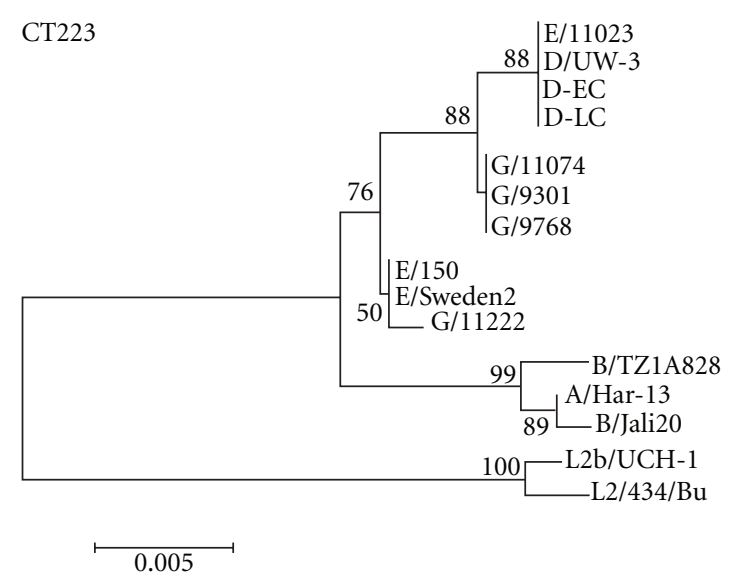

(a)

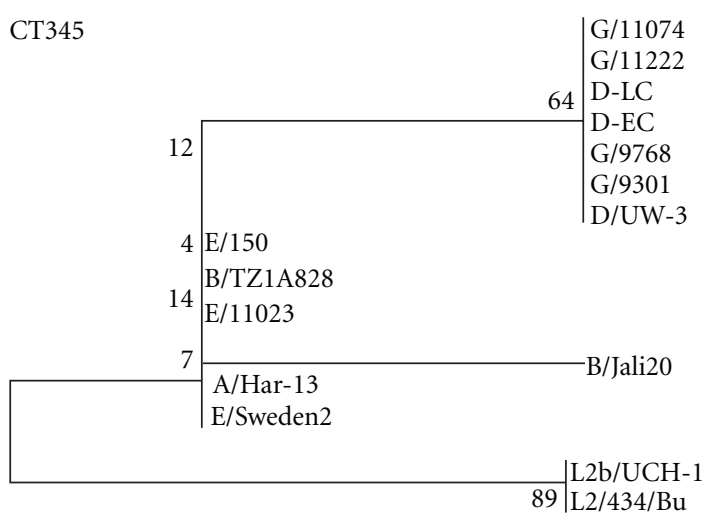

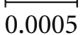

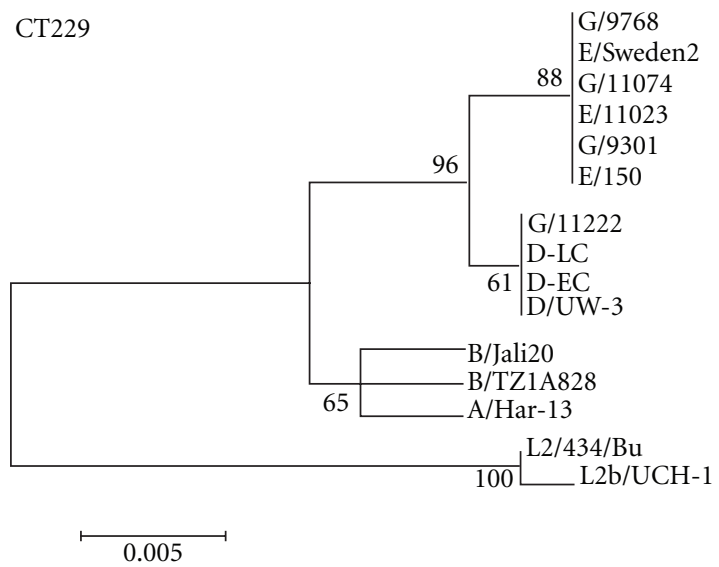

(b)

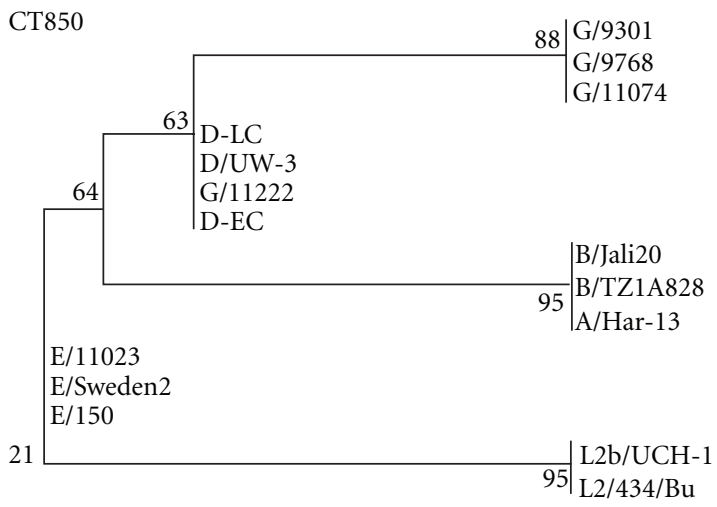

$\stackrel{20002}{0.002}$

Figure 2: Phylogenetic reconstructions of C. trachomatis Incs displaying tissue tropism clusters. Evolutionary history of Incs was inferred with the Neighbor-Joining method using the bootstrap test with 1000 replicates with the percentage of replicate trees associated with each clustered group shown next to the branches. Incs CT223 and CT229 cluster separate clades for ocular, genital, and LGV strains (a and b), CT345 clusters a separate LGV clade (c), and CT850 clusters separate LGV, ocular, and serovar E clades (d).

clades. These findings suggest the possibility that specific Incs may be evolving towards different infection strategies for different host tissues. A microarray analysis of niche specific genes previously identified four Incs, CT116, CT223, CT288, and CT618 as LGV specific [45] which were also identified in our study. However, no other Incs in that study were correlated with tissue tropism or clinical grouping.

The greater phylogenetic divergence of those Incs producing separate LGV clades suggests that Incs within LGV strains may be undergoing evolutionary divergence at rates greater than those of other clinical groupings. This divergence has been noted with other phylogenetically defined tissue tropic genes including $\operatorname{tar} P[37]$ and the pmps $[32,36]$. Phylogenetic analysis of $\operatorname{tar} P$ indicated that the LGV isolates were the first to diverge to produce a distinct clade containing L1-L3 isolates [37]. A similar divergence of LGV strains was seen for the pmps $[32,36]$. This suggests that the evolutionary trend seen with the Incs in which LGV isolates appear more evolutionarily distinct coincides with other characterized genetic loci. It may be that LGV isolates in general show the greatest evolutionary divergence and that this divergence may not be limited to genes predicted to contribute to tissue tropism. The infections caused by LGV isolates differ from those caused by the ocular and urogenital serovars in that they are able to replicate within macrophages and cause a more invasive, systemic disease than the infections of mucosal epithelium caused by the ocular and urogenital strains [46]. The differences in host selective pressures may be driving the evolutionary differences seen within the LGV Incs as well as other loci.

3.3. Conservation of Incs between Chlamydiae Species. The same computational approach used for $C$. trachomatis was implemented to predict Incs for C. caviae, C. felis, C. muridarum, and C. pneumoniae (Table 1). All predicted Incs were cross-referenced to the other genomes using PSI-BLAST in attempts to identify divergent homologues in other species. Certain predicted Incs appear more than once in Table 1 due to potential similarity to more than one identified homologue. C. pneumoniae was predicted to contain the most Incs 

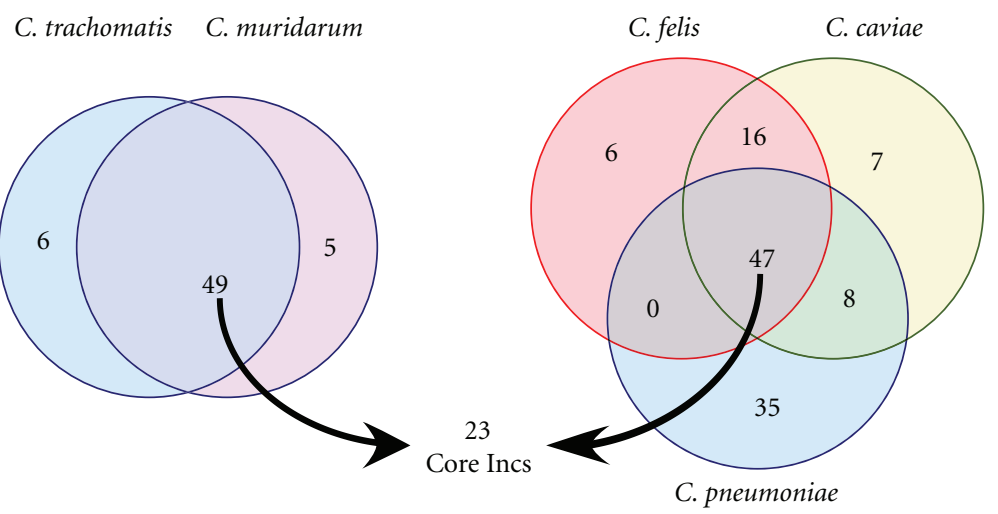

FIgURE 3: Venn diagram analysis of shared Inc homologues across Chlamydiae species. Two Venn diagrams are depicted showing shared Incs between C. trachomatis and C. muridarum (a) and between C. felis, C. caviae, and C. pneumoniae (b). Homologues that lacked an identifiable bilobed hydrophobic domain by Kyte and Doolittle analysis were not counted in the Venn diagram analysis. The numbers in the Venn diagram for C. felis, C. caviae, and C. pneumoniae total less than the total number of Incs defined for each species as only homologous sets of Incs were counted as one.

(92) with C. felis and C. caviae possessing 69 and 79, respectively. C. trachomatis and C. muridarum contained the fewest number of Incs within this comparison consisting of 55 and 54, respectively. Again, the predictions were highly overlapping but not identical to previous predictions [16, 18-22].

We were able to define a core subset of 23 Incs for which homologues could be identified in all five Chlamydiae species. C. trachomatis and C. muridarum were found to be the most related sharing 49 Inc homologues but also showed differences with each species containing unique Incs: 6 for C. trachomatis and 5 for C. muridarum (Figure 3, Table 1). The three remaining species, C. felis, C. caviae, and C. pneumoniae, also appeared very similar in that they shared a core of 47 Inc homologues. A pairwise comparison of these latter three species also identified shared Incs between any two given species with $C$. felis and $C$. caviae sharing a minimum 16 Incs, C. caviae and C. pneumoniae sharing 8, and C. felis and $C$. pneumoniae not sharing any outside of the core Incs (Figure 3, Table 1). Incs that appeared to be expanded in that there were more than one homologue per genome were only counted once in the Venn diagram. Genomic comparisons between all five species identified a core family of 23 conserved Incs for which Inc homologues are present in all species (CT005, CT006, CT058, CT134, CT179, CT195, CT232, CT233, CT288, CT324, CT365, CT383, CT440, CT449, CT483, CT484, CT565, CT616, CT618, CT642, CT728, CT788, and CT850) (Figure 3, Table 1). The analysis also identified Incs that were unique to each species (Table 1).

Generally, if an Inc was identified in one species, then its homologues in other species were also identified as Incs, although some exceptions were noted (Table 1). C. pneumoniae CP0481 was identified as an Inc based on the presence of a bilobed hydrophobic domain whereas its homologues in C. caviae (CCA00586) and C. felis (CF0422) lack the characteristic bilobed hydrophobic domain. C. pneumoniae also encodes CP0667 which lacks a bilobed hydrophobic domain but contains homologues to CP0667 that do contain the hydrophobic domain (CP0387, CP0388, and CP0390; Table 1). Homologues to CP0667 in all four other chlamydial species also contain the characteristic bilobed hydrophobic domain (Table 1). C. trachomatis contained two genes which lacked a discernible bilobed hydrophobic domain; however the homologues of these genes in other chlamydial species are predicted to contain the characteristic hydrophobic bilobed domain (Table 1). As such, it appears that most Inc homologues maintain the bilobed hydrophobic domain.

Comparison of Incs between species provided an opportunity to evaluate the overall topology and conservation of Incs. Each Inc and its corresponding homologues identified were evaluated for the presence or absence of the characteristic bilobed hydrophobic domain. It was found that homologues of most Incs also contained a bilobed hydrophobic domain and that those homologues were also identified as Incs within this study suggesting that an Inc in one species has a corresponding homologue that is also an Inc in another species. Interestingly, the overall hydrophobic topology of the homologues was maintained despite a great degree of sequence divergence (an overall conserved identity of $27.3 \%$ for CT483 and $17.2 \%$ for CT850 at the amino acid level). Figure 4 illustrates two examples of Inc homologues that were identified in all five species, CT850 (a) and CT483 (b). Not only the presence of the bilobed hydrophobic domain but also its location was conserved suggesting that the bilobed hydrophobic domain is an integral part of an Inc protein.

Examination of all chlamydial species for which sequenced genomes were available indicates that the predicted Incs within each species represent a significant fraction of the genome. Overall, a great diversity of Incs was identified, not only those which are shared between species but also those which appeared to be unique to each individual species. It is possible that Incs present in only one species may play a role 

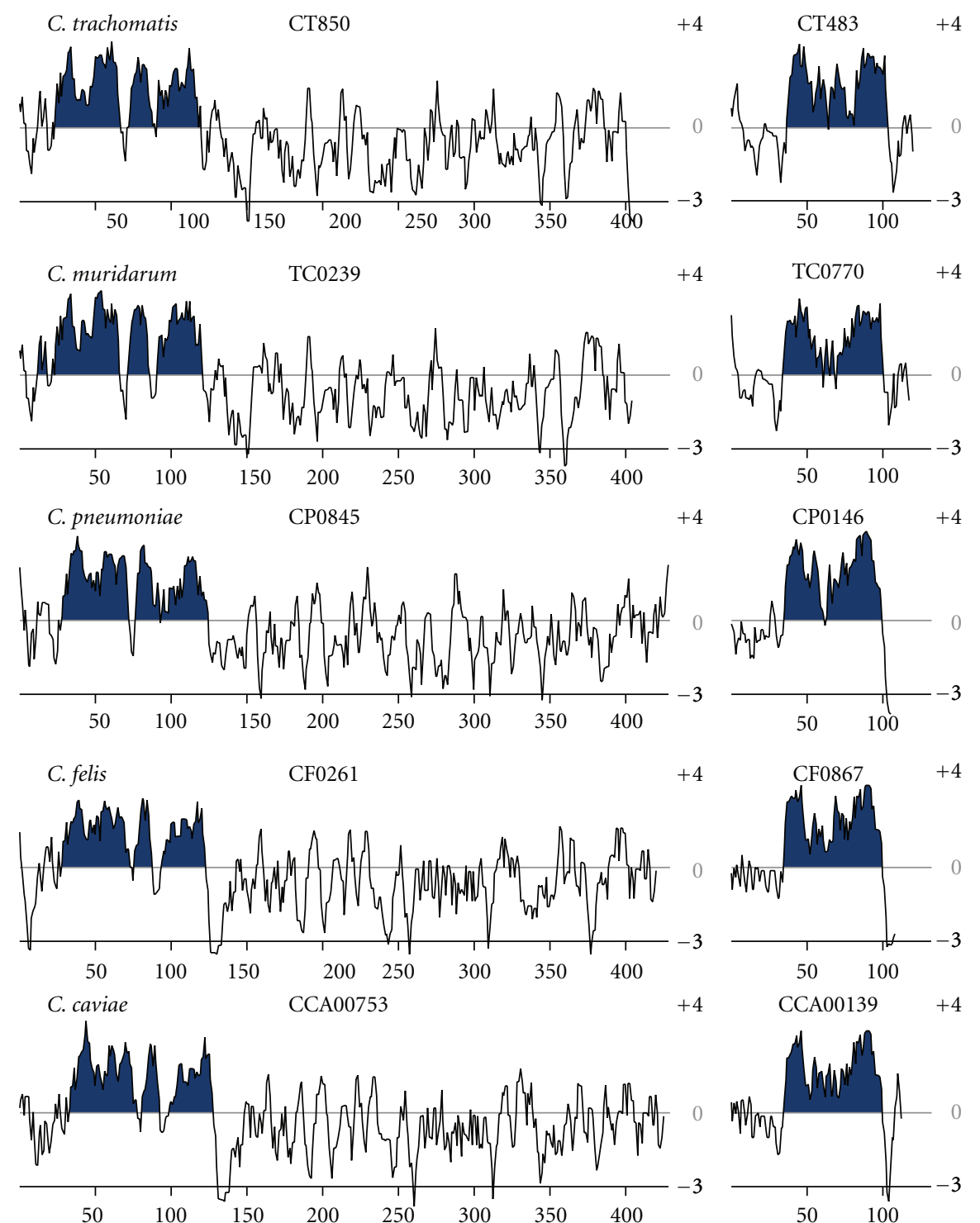

(a)

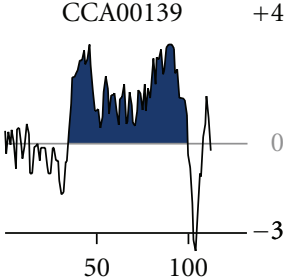

(b)

Figure 4: Hydropathy plot analysis and conservation of core Incs. Incs CT850 (a) and CT483 (b) from C. trachomatis, C. muridarum, C. pneumoniae, C. felis, and C. caviae were visualized using Kyte and Doolittle hydropathy plots. Regions of the bilobed hydrophobic domain are shown shaded.

in infection that is unique to that species. There were also 23 Incs identified in all five species. These Incs represent core Incs that may be involved in conserved interactions with the host cell.

Very few of the known Incs have had functions assigned. IncA, first identified in C. caviae [47], is required for the homotypic fusion of inclusions in cells multiply infected with C. trachomatis [14] and when transfected into host cells blocks C. caviae development [48]. IncA appears to be nonessential for $C$. trachomatis survival and multiplication since clinical isolates of $C$. trachomatis lacking IncA have been isolated from patients [49]. IncA has been shown to have structural similarities to SNARE (soluble NSF (Nethylmaleimide-sensitive factor) attachment protein receptors) proteins, a class of membrane proteins that control the specificity of vesicle fusion [50]. IncA has been shown to interact with the SNARE proteins Vamp3, Vamp7, and Vamp8 although depletion of these three SNAREs by siRNA had no deleterious impact on chlamydial growth [50]. A number of Rab-family GTPases are recruited to the chlamydial inclusion membrane in a species-dependent manner [51] and it appears that certain Inc proteins may play a role in specific Rab recruitment to the inclusion membrane. $C$. trachomatis CT229 mediates recruitment of Rab 4 [52] and C. pneumoniae Cpn585 displays affinity for Rab 1, Rab 10, and Rab 11 [53]. Other Incs known to recruit host proteins include IncG, which recruits the adaptor molecule 14-3-3 $\beta$ in a species-specific fashion [13]. Although a few Inc functions and interactions with host components have been identified, they are for the most part restricted to unique chlamydial 


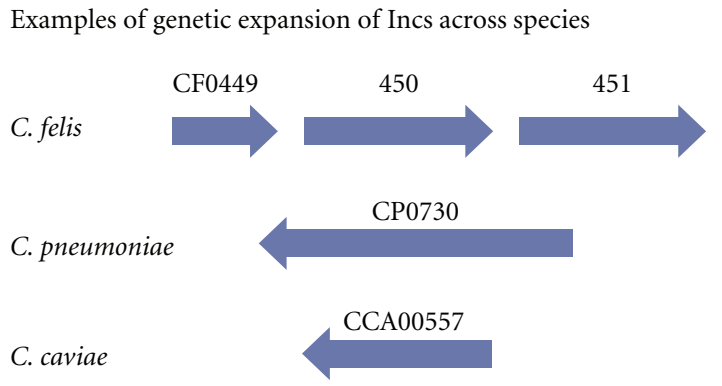

(a)

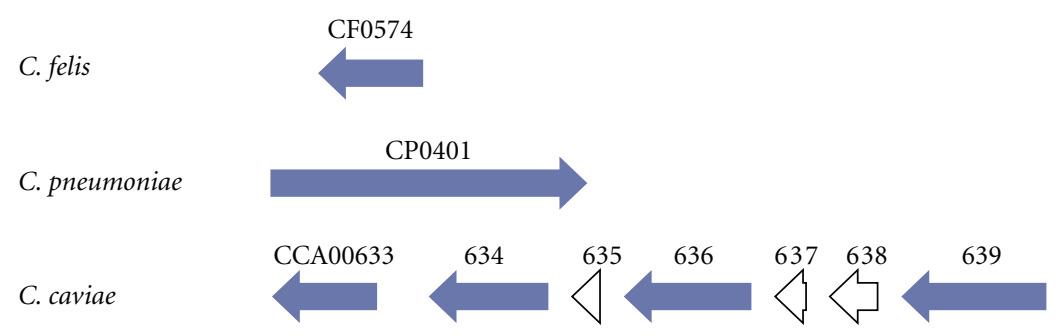

(b)
C. felis
C. pneumoniae
C. caviae
C. muridarum
C. trachomatis

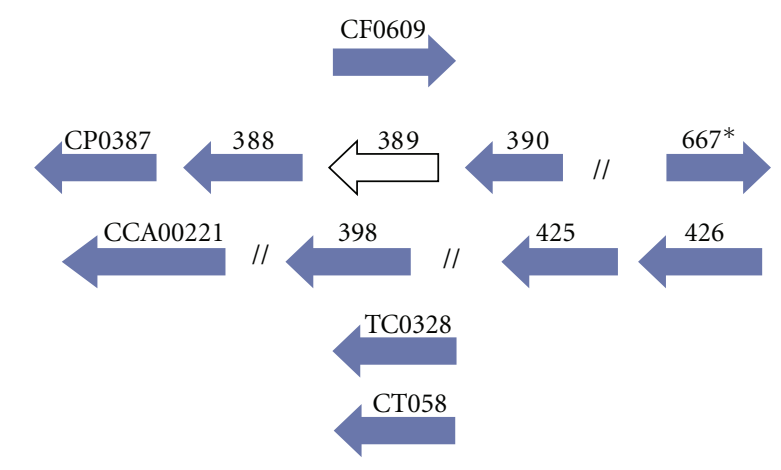

(c)

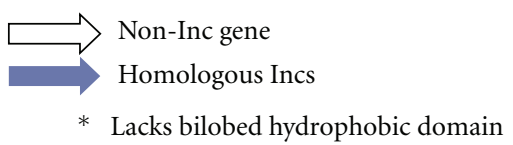

Figure 5: Examples of Inc expansion in C. caviae, C. felis, and C. pneumoniae. Three loci are depicted showing Inc expansion in C. felis (a), C. caviae (b), and C. caviae and C. pneumoniae (b and c). ${ }^{*}$ designates that the predicted gene products lack the bilobed hydrophobic domain.

species. One possibility is that the function of the majority of Incs and a reason for their duplication and diversity may not necessarily involve specific interactions with the host cell but be related to their unique hydrophobic structure and potential roles in the structural integrity of the inclusion membrane.

3.4. Genetic Expansion of Incs within Different Chlamydiae Strains. The C. trachomatis and C. muridarum genomes contained operons or clusters of Incs in which there was little sequence similarity between Inc open reading frames (CT115-119; CT222-229, Table 1). Although these Incs cluster together in the genome, they appear to have arisen independently of each other or may represent expansion of an ancestral inc that diverged at a rapid rate. In contrast, C. felis, C. pneumonia, and C. caviae each contained Inc operons in which there were intracluster similarities suggesting gene expansion within these genomes (Figure 5(c), Table 1). Additionally, orthologous Incs could be located outside of operons in other regions of the genome. Multiple examples of duplicated Incs could be identified in C. felis, C. pneumonia, and C. caviae however none were identified in C. trachomatis or C. muridarum (Table 1). C. felis contained three examples of Inc expansion, one of which is illustrated in Figure 5(a). The operon containing Incs CF0449-CF0451 had intracluster similarity but only a single identifiable homologue in either C. caviae (CCA00557) or C. pneumoniae (CP0730) (Figure 5(a)). C. caviae contained three genetic expansions of 
Incs, two of which are depicted in Figures 5(b) and 5(c). One Inc cluster (CCA00633-CCA00639) contained three nonInc genes within the operon and was homologues to only one Inc in C. felis (CF0574) or C. pneumoniae (CP0401) (Figure 5(b)). The second Inc expansion (CCA00425, CCA00426, CCA00221, and CCA00398) corresponded to an Inc expansion in C. pneumoniae (CP0397-CP0390; CP0667), where one homologue, CP0667, did not contain an identifiable bilobed hydrophobic domain (Figure 5(c)). C. pneumoniae not only contained the greatest number of Incs but also exhibited the most Inc expansions (eight) of the species examined, one of which is depicted in Figure 5(c).

The advent of genome sequencing and comparative genomics has led to the recognition that there has been genetic expansion of genes from C. pneumoniae [54, 55], C. caviae [56] but not C. felis. Initial comparisons between C. pneumoniae and C. trachomatis genomes showed a high degree of sequence conservation and synteny but also noted a remarkable increase in the number of predicted Pmp genes. C. pneumoniae encodes for $21 \mathrm{Pmps}$ while C. trachomatis encodes for only 9 [54]. The amplification of the Pmp family of proteins suggests that either C. pneumoniae contains mechanisms that enhance genetic expansion and diversity or, alternatively, the unique biology of $C$. pneumoniae may have selected for these expansions. Similarly, we were able to identify Incs that have been expanded in $C$. pneumoniae, $C$. caviae, and C. felis. The genetic expansion of CT058 homologues was one of the most prominent in our study with C. caviae and C. pneumoniae each having four homologues. The regions flanking these genes also show a high degree of conservation [55]. Incs unique to C. pneumoniae appear to have undergone genetic expansion. C. pneumoniae lacks an IncA homologue but encodes a closely related set of Inc paralogues that are predicted to contain an IncA domain [57]. This group of paralogous genes has previously been referred to as the CP1054 family and each of these is shown to contain the characteristic bilobed hydrophobic domain characteristic of Incs. The reason for the level of genetic expansion seen in C. pneumoniae, C. caviae, and C. felis is uncertain but may represent a level of redundancy that is advantageous for these species with regards to infection or transmission that is not necessary for $C$. trachomatis or $C$. muridarum.

While the analyses here are focused upon the human and veterinary pathogens that comprise the genus Chlamydia, members of the so-called environmental chlamydia of the family Parachlamydiaceae also express proteins displaying the characteristic bilobed hydrophobic structure of chlamydial inclusion membrane proteins. The Parachlamydiaceae are obligate intracellular symbiotes of amoebae believed to be ancestral to the pathogenic Chlamydia and contain several of the virulence factors expressed in Chlamydia. The genomes of the environmental chlamydiae are larger; that of Protochlamydia amoebophila is approximately $2.41 \mathrm{Mbp}$ [58] versus that of $C$. trachomatis serovar D which is $1.04 \mathrm{Mbp}$ [34]. Despite the much larger genome, the number of putative Incs in P. amoebophila is only twenty-three [59]. Of these, only three (pc0156, pc0184, and pc1857) bear significant similarity to chlamydial Incs and the Incs to which they are most closely related are among the core Incs identified here in Chlamydia spp. Like the chlamydial inclusion membrane proteins, the functions of the Incs from $P$. amoebophila are largely unknown although five of these have been confirmed as localized to the inclusion membrane [59], and thus the predictive value of the bilobed hydrophobic domain appears to be viable in this family as well.

\section{Conclusions}

The chlamydial inclusion is extensively modified very early in infection by the insertion of a family of type III secreted effector proteins collectively known as Incs. Once the inclusion membrane is modified by de novo synthesized chlamydial proteins, a number of interactions with the host cell are initiated $[6,7,60-62]$. The unique interactions of the chlamydial inclusion with the host cell and biological similarities between chlamydial species would lead one to predict that pathogen proteins situated to potentially influence interactions might be conserved among chlamydiae. The Inc genes are, however, among the most variable between chlamydial genomes with only a relatively small number of orthologs conserved in all species [19]. Instead, each chlamydial species contains a number of unique Incs. A comparative genomics approach coupled with phylogenetic analysis was therefore applied to predicted Inc proteins of $C$. trachomatis, C. muridarum, C. caviae, C. felis, and C. pneumoniae in an effort to identify those Incs that might contribute to conserved functions. Using this approach, a core set of 23 Incs was identified.

Taken together, our data suggest that there is a high degree of conservation of Inc proteins within serovars of $C$. trachomatis but that specific Incs show evidence of evolutionary divergence that phylogenetically separate certain Incs into clinical clusters (LGV, ocular, and urogenital). By taking a comparative genomics approach, a core set of Incs were identified which are common to all five species examined. The core Inc genes identified may represent proteins involved in conserved interactions between the chlamydia and host. Incs unique to each species were also identified. The diversification of Incs between species suggests that certain Incs may have evolved unique pathogenic roles within these species. A more complete understanding of the interactions of the Inc proteins may provide for new insights into chlamydial pathogenesis.

\section{Acknowledgments}

This work was supported by the Intramural Research Program of the NIH/NIAID. The authors thank Drs. J. Carlson, L. Bauler, J. Mital, A. Omsland, and T. Clark for critical review of the manuscript.

\section{References}

[1] J. Schachter, "Infection and disease epidemiology," in Chlamydia: Intracellular Biology, Pathogenesis, and Immunity, R. S. 
Stephens, Ed., pp. 139-169, ASM Press, Washington, DC, USA, 1999.

[2] J. T. Grayston, M. B. Aldous, A. Easton et al., "Evidence that Chlamydia pneumoniae causes pneumonia and bronchitis," Journal of Infectious Diseases, vol. 168, no. 5, pp. 1231-1235, 1993.

[3] P. Saikku, K. Mattila, M. S. Nieminen et al., "Serological evidence of an association of a novel chlamydia, TWAR, with chronic coronary heart disease and acute myocardial infarction," The Lancet, vol. 2, no. 8618, pp. 983-986, 1988.

[4] J. E. Sykes, "Feline chlamydiosis," Clinical Techniques in Small Animal Practice, vol. 20, no. 2, pp. 129-134, 2005.

[5] C. Nigg and M. D. Eaton, "Isolation from normal mice of a pneumotropic virus which forms elementary bodies," Journal of Experimental Medicine, vol. 79, pp. 497-510, 1944.

[6] R. A. Carabeo, D. J. Mead, and T. Hackstadt, "Golgi-dependent transport of cholesterol to the Chlamydia trachomatis inclusion," Proceedings of the National Academy of Sciences of the United States of America, vol. 100, no. 11, pp. 6771-6776, 2003.

[7] T. Hackstadt, D. D. Rockey, R. A. Heinzen, and M. A. Scidmore, "Chlamydia trachomatis interrupts an exocytic pathway to acquire endogenously synthesized sphingomyelin in transit from the Golgi apparatus to the plasma membrane," EMBO Journal, vol. 15, no. 5, pp. 964-977, 1996.

[8] T. Hackstadt, M. A. Scidmore, and D. D. Rockey, "Lipid metabolism in Chlamydia trachomatis-infected cells: directed trafficking of Golgi-derived sphingolipids to the chlamydial inclusion," Proceedings of the National Academy of Sciences of the United States of America, vol. 92, no. 11, pp. 4877-4881, 1995.

[9] W. L. Beatty, "Late endocytic multivesicular bodies intersect the chlamydial inclusion in the absence of CD63," Infection and Immunity, vol. 76, no. 7, pp. 2872-2881, 2008.

[10] Y. Kumar, J. Cocchiaro, and R. H. Valdivia, "The obligate intracellular pathogen chlamydia trachomatis targets host lipid droplets," Current Biology, vol. 16, no. 16, pp. 1646-1651, 2006.

[11] J. Mital, N. J. Miller, E. R. Fischer, and T. Hackstadt, "Specific chlamydial inclusion membrane proteins associate with active Src family kinases in microdomains that interact with the host microtubule network," Cellular Microbiology, vol. 12, no. 9, pp. 1235-1249, 2010.

[12] E. R. Moore, E. R. Fischer, D. J. Mead, and T. Hackstadt, "The chlamydial inclusion preferentially intercepts basolaterally directed sphingomyelin-containing exocytic vacuoles," Traffic, vol. 9, no. 12, pp. 2130-2140, 2008.

[13] M. A. Scidmore and T. Hackstadt, "Mammalian 14-3-3 $\beta$ associates with the Chlamydia trachomatis inclusion membrane via its interaction with IncG," Molecular Microbiology, vol. 39, no. 6, pp. 1638-1650, 2001.

[14] T. Hackstadt, M. A. Scidmore-Carlson, E. I. Shaw, and E. R. Fischer, "The Chlamydia trachomatis IncA protein is required for homotypic vesicle fusion," Cellular Microbiology, vol. 1, no. 2, pp. 119-130, 1999.

[15] D. D. Rockey, D. Grosenbach, D. E. Hruby, M. G. Peacock, R. A. Heinzen, and T. Hackstadt, "Chlamydia psittaci IncA is phosphorylated by the host cell and is exposed on the cytoplasmic face of the developing inclusion," Molecular Microbiology, vol. 24, no. 1, pp. 217-228, 1997.

[16] J. P. Bannantine, R. S. Griffiths, W. Viratyosin, W. J. Brown, and D. D. Rockey, "A secondary structure motif predictive of protein localization to the chlamydial inclusion membrane," Cellular Microbiology, vol. 2, no. 1, pp. 35-47, 2000.
[17] D. D. Rockey, M. A. Scidmore, J. P. Bannantine, and W. J. Brown, "Proteins in the chlamydial inclusion membrane," Microbes and Infection, vol. 4, no. 3, pp. 333-340, 2002.

[18] H. Toh, K. Miura, M. Shirai, and M. Hattori, "In silico inference of inclusion membrane protein family in obligate intracellular parasites chlamydiae," DNA Research, vol. 10, no. 1, pp. 9-17, 2003.

[19] P. Dehoux, R. Flores, C. Dauga, G. Zhong, and A. Subtil, "Multi-genome identification and characterization of chlamydiae-specific type III secretion substrates: the Inc proteins," BMC Genomics, vol. 12, article 109, 2011.

[20] Z. Li, C. Chen, D. Chen, Y. Wu, Y. Zhong, and G. Zhong, "Characterization of fifty putative inclusion membrane proteins encoded in the Chlamydia trachomatis genome," Infection and Immunity, vol. 76, pp. 2746-2757, 2008.

[21] E. I. Shaw, C. A. Dooley, E. R. Fischer, M. A. Scidmore, K. A. Fields, and T. Hackstadt, "Three temporal classes of gene expression during the Chlamydia trachomatis developmental cycle," Molecular Microbiology, vol. 37, pp. 913-925, 2000.

[22] Y. Azuma, H. Hirakawa, A. Yamashita et al., "Genome sequence of the cat pathogen, Chlamydophila felis," DNA Research, vol. 13, no. 1, pp. 15-23, 2006.

[23] J. Kyte and R. F. Doolittle, "A simple method for displaying the hydropathic character of a protein," Journal of Molecular Biology, vol. 157, no. 1, pp. 105-132, 1982.

[24] A. Krogh, B. Larsson, G. von Heijne, and E. L. L. Sonnhammer, "Predicting transmembrane protein topology with a hidden Markov model: application to complete genomes," Journal of Molecular Biology, vol. 305, no. 3, pp. 567-580, 2001.

[25] S. F. Altschul, T. L. Madden, A. A. Schaffer et al., "Gapped BLAST and PSI-BLAST: a new generation of protein database search programs," Nucleic Acids Research, vol. 25, no. 17, pp. 3389-3402, 1997.

[26] J. D. Thompson, D. G. Higgins, and T. J. Gibson, "CLUSTAL $\mathrm{W}$ : improving the sensitivity of progressive multiple sequence alignment through sequence weighting, position-specific gap penalties and weight matrix choice," Nucleic Acids Research, vol. 22, no. 22, pp. 4673-4680, 1994.

[27] N. Saitou and M. Nei, "The neighbor-joining method: a new method for reconstructing phylogenetic trees," Molecular Biology and Evolution, vol. 4, no. 4, pp. 406-425, 1987.

[28] K. Tamura, J. Dudley, M. Nei, and S. Kumar, "MEGA4: molecular evolutionary genetics analysis (MEGA) software version 4.0," Molecular Biology and Evolution, vol. 24, no. 8, pp. 1596-1599, 2007.

[29] J. Felsenstein, "Confidence-limits on phylogenies-an approach using the bootstrap," Evolution, vol. 39, pp. 783-791, 1985.

[30] K. Tamura, M. Nei, and S. Kumar, "Prospects for inferring very large phylogenies by using the neighbor-joining method," Proceedings of the National Academy of Sciences of the United States of America, vol. 101, no. 30, pp. 11030-11035, 2004.

[31] M. Nei and T. Gojobori, "Simple methods for estimating the numbers of synonymous and nonsynonymous nucleotide substitutions," Molecular Biology and Evolution, vol. 3, no. 5, pp. 418-426, 1986.

[32] J. P. Gomes, A. Nunes, W. J. Bruno, M. J. Borrego, C. Florindo, and D. Dean, "Polymorphisms in the nine polymorphic membrane proteins of Chlamydia trachomatis across all serovars: evidence for serovar da recombination and correlation with tissue tropism," Journal of Bacteriology, vol. 188, no. 1, pp. 275-286, 2006.

[33] J. H. Carlson, S. F. Porcella, G. McClarty, and H. D. Caldwell, "Comparative genomic analysis of Chlamydia trachomatis 
oculotropic and genitotropic strains," Infection and Immunity, vol. 73, no. 10, pp. 6407-6418, 2005.

[34] R. S. Stephens, S. Kalman, C. Lammel et al., "Genome sequence of an obligate intracellular pathogen of humans: Chlamydia trachomatis," Science, vol. 282, no. 5389, pp. 754-759, 1998.

[35] N. R. Thomson, M. T. G. Holden, C. Carder et al., "Chlamydia trachomatis: genome sequence analysis of lymphogranuloma venereum isolates," Genome Research, vol. 18, no. 1, pp. 161$171,2008$.

[36] D. R. Stothard, G. A. Toth, and B. E. Batteiger, "Polymorphic membrane protein $\mathrm{H}$ has evolved in parallel with the three disease-causing groups of Chlamydia trachomatis," Infection and Immunity, vol. 71, no. 3, pp. 1200-1208, 2003.

[37] E. I. Lutter, C. Bonner, M. J. Holland et al., "Phylogenetic analysis of Chlamydia trachomatis tarp and correlation with clinical phenotype," Infection and Immunity, vol. 78, no. 9, pp. 3678-3688, 2010.

[38] R. J. Belland, M. A. Scidmore, D. D. Crane et al., "Chlamydia trachomatis cytotoxicity associated with complete and partial cytotoxin genes," Proceedings of the National Academy of Sciences of the United States of America, vol. 98, no. 24, pp. 1398413989, 2001.

[39] J. H. Carlson, S. Hughes, D. Hogan et al., "Polymorphisms in the Chlamydia trachomatis cytotoxin locus associated with ocular and genital isolates," Infection and Immunity, vol. 72, no. 12, pp. 7063-7072, 2004.

[40] H. D. Caldwell, H. Wood, D. Crane et al., "Polymorphisms in Chlamydia trachomatis tryptophan synthase genes differentiate between genital and ocular isolates," Journal of Clinical Investigation, vol. 111, no. 11, pp. 1757-1769, 2003.

[41] C. Fehlner-Gardiner, C. Roshick, J. H. Carlson et al., "Molecular basis defining human Chlamydia trachomatis tissue tropism: a possible role for tryptophan synthase," The Journal of Biological Chemistry, vol. 277, no. 30, pp. 26893-26903, 2002.

[42] A. C. Shaw, G. Christiansen, P. Roepstorff, and S. Birkelund, "Genetic differences in the Chlamydia trachomatis tryptophan synthase $\alpha$-subunit can explain variations in serovar pathogenesis," Microbes and Infection, vol. 2, no. 6, pp. 581-592, 2000.

[43] T. Hackstadt, T. J. Brickman, C. E. Barry, and J. Sager, "Diverity in the Chlamydia trachomatis histone homologue Hc2," Gene, vol. 132, no. 1, pp. 137-141, 1993.

[44] M. Klint, M. Thollesson, E. Bongcam-Rudloff, S. Birkelund, A. Nilsson, and B. Herrmann, "Mosaic structure of intragenic repetitive elements in histone H1-like protein Hc2 varies within serovars of Chlamydia trachomatis," BMC Microbiology, vol. 10, article 81, 2010.

[45] B. W. Brunelle, T. L. Nicholson, and R. S. Stephens, "Microarray-based genomic surveying of gene polymorphisms in Chlamydia trachomatis," Genome Biology, vol. 5, no. 6, article R42, 2004.

[46] E. C. Yong, E. Y. Chi, and C. C. Kuo, "Differential antimicrobial activity of human mononuclear phagocytes against the human biovars of Chlamydia trachomatis," Journal of Immunology, vol. 139, no. 4, pp. 1297-1302, 1987.

[47] D. D. Rockey, R. A. Heinzen, and T. Hackstadt, "Cloning and characterization of a Chlamydia psittaci gene coding for a protein localized in the inclusion membrane of infected cells," Molecular Microbiology, vol. 15, no. 4, pp. 617-626, 1995.

[48] D. Alzhanov, J. Barnes, D. E. Hruby, and D. D. Rockey, "Chlamydial development is blocked in host cells transfected with Chlamydophila caviae incA," BMC Microbiology, vol. 4, article 24, 2004.

[49] R. J. Suchland, D. D. Rockey, J. P. Bannantine, and W. E. Stamm, "Isolates of Chlamydia trachomatis that occupy nonfusogenic inclusions lack IncA, a protein localized to the inclusion membrane," Infection and Immunity, vol. 68, no. 1, pp. 360-367, 2000.

[50] C. Delevoye, M. Nilges, P. Dehoux et al., "SNARE protein mimicry by an intracellular bacterium," PLoS Pathogens, vol. 4, no. 3, Article ID e1000022, 2008.

[51] K. A. Rzomp, L. D. Scholtes, B. J. Briggs, G. R. Whittaker, and M. A. Scidmore, "Rab GTPases are recruited to chlamydial inclusions in both a species-dependent and speciesindependent manner," Infection and Immunity, vol. 71, no. 10, pp. 5855-5870, 2003.

[52] K. A. Rzomp, A. R. Moorhead, and M. A. Scidmore, "The GTPase Rab4 interacts with Chlamydia trachomatis inclusion membrane protein CT229," Infection and Immunity, vol. 74, no. 9, pp. 5362-5373, 2006.

[53] C. Cortes, K. A. Rzomp, A. Tvinnereim, M. A. Scidmore, and B. Wizel, "Chlamydia pneumoniae inclusion membrane protein Cpn0585 interacts with multiple Rab GTPases," Infection and Immunity, vol. 75, no. 12, pp. 5586-5596, 2007.

[54] S. Kalman, W. Mitchell, R. Marathe et al., "Comparative genomes of Chlamydia pneumoniae and C. trachomatis," Nature Genetics, vol. 21, no. 4, pp. 385-389, 1999.

[55] T. D. Read, R. C. Brunham, C. Shen et al., "Genome sequences of Chlamydia trachomatis MoPn and Chlamydia pneumoniae AR39," Nucleic Acids Research, vol. 28, no. 6, pp. 1397-1406, 2000.

[56] T. D. Read, G. S. A. Myers, R. C. Brunham et al., "Genome sequence of Chlamydophila caviae (Chlamydia psittaci GPIC): examining the role of niche-specific genes in the evolution of the Chlamydiaceae," Nucleic Acids Research, vol. 31, no. 8, pp. 2134-2147, 2003.

[57] W. Viratyosin, L. A. Campbell, C. C. Kuo, and D. D. Roc$\mathrm{key}$, "Intrastrain and interstrain genetic variation within a paralogous gene family in Chlamydia pneumoniae," BMC Microbiology, vol. 2, no. 1, article 38, 2002.

[58] M. Horn, A. Collingro, S. Schmitz-Esser et al., "Illuminating the evolutionary history of chlamydiae," Science, vol. 304, no. 5671, pp. 728-730, 2004.

[59] E. Heinz, D. D. Rockey, J. Montanaro, K. Aistleitner, M. Wagner, and M. Horn, "Inclusion membrane proteins of Protochlamydia amoebophila UWE25 reveal a conserved mechanism for host cell interaction among the Chlamydiae," Journal of Bacteriology, vol. 192, no. 19, pp. 5093-5102, 2010.

[60] J. D. Clausen, G. Christiansen, H. U. Holst, and S. Birkelund, "Chlamydia trachomatis utilizes the host cell microtubule network during early events of infection," Molecular Microbiology, vol. 25, no. 3, pp. 441-449, 1997.

[61] S. S. Grieshaber, N. A. Grieshaber, and T. Hackstadt, "Chlam$y$ dia trachomatis uses host cell dynein to traffic to the microtubule-organizing center in a p50 dynamitin-independent process," Journal of Cell Science, vol. 116, no. 18, pp. 3793-3802, 2003.

[62] M. A. Scidmore, D. D. Rockey, E. R. Fischer, R. A. Heinzen, and T. Hackstadt, "Vesicular interactions of the Chlamydia trachomatis inclusion are determined by chlamydial early protein synthesis rather than route of entry," Infection and Immunity, vol. 64 , no. 12 , pp. 5366-5372, 1996. 

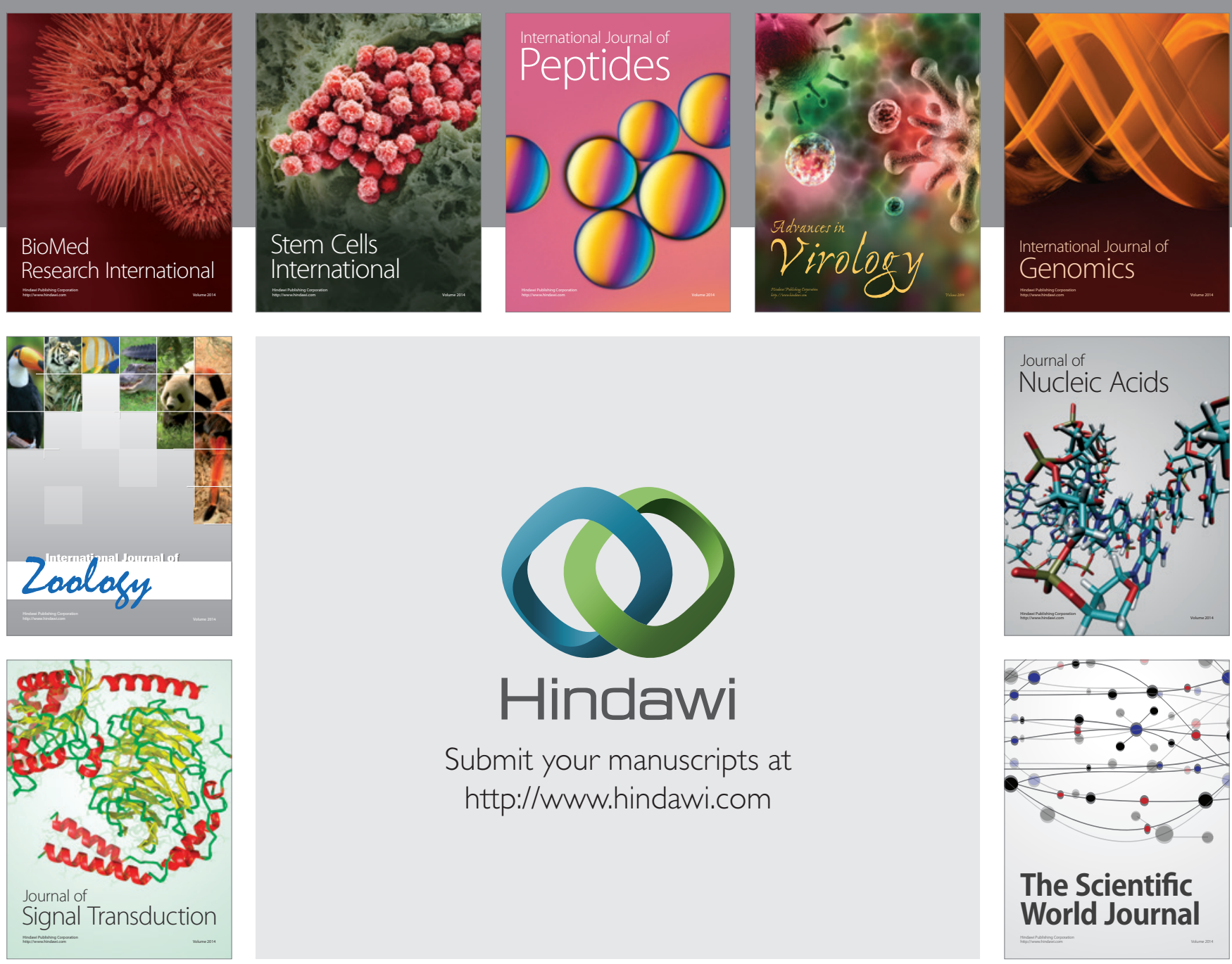

Submit your manuscripts at

http://www.hindawi.com
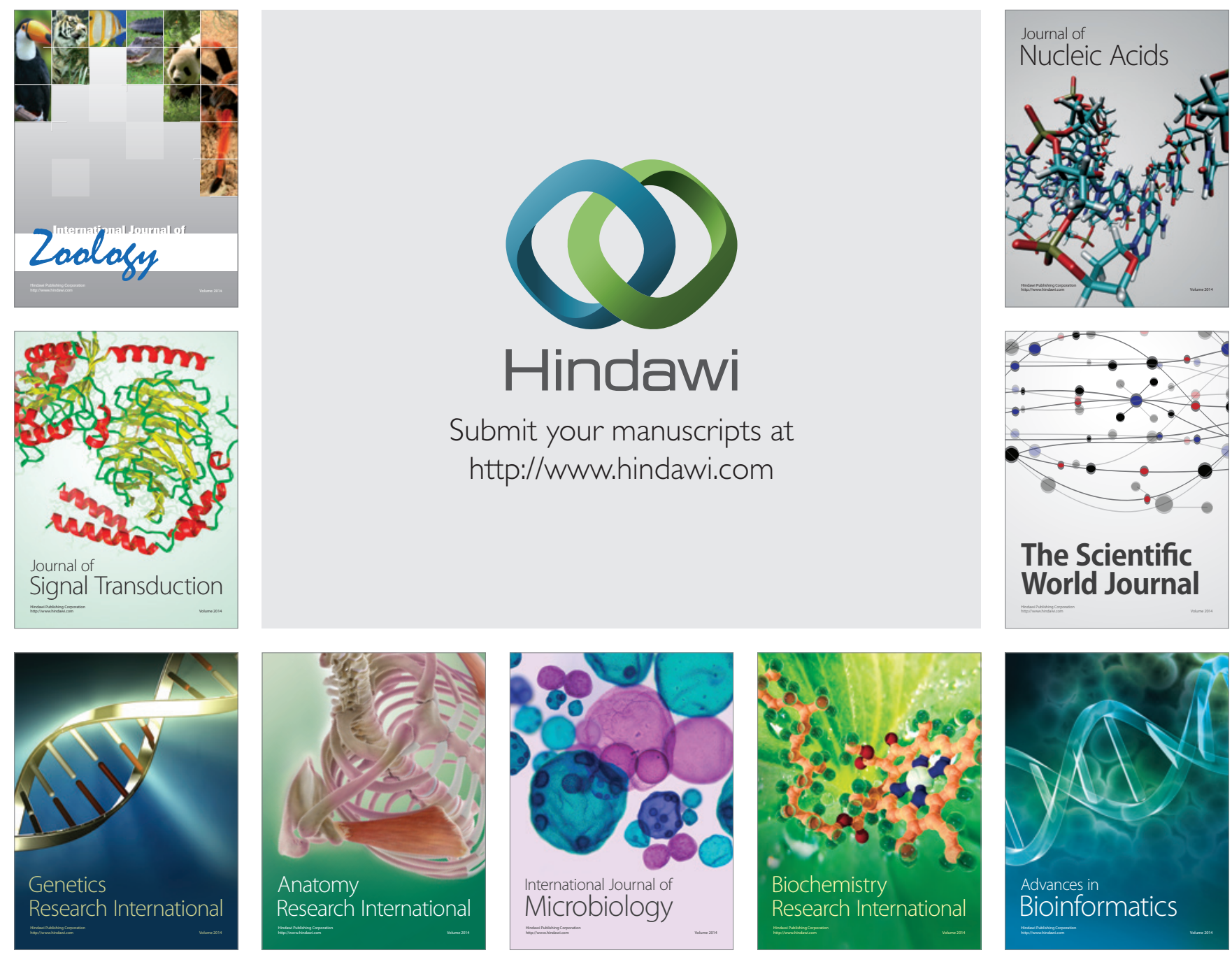

The Scientific World Journal
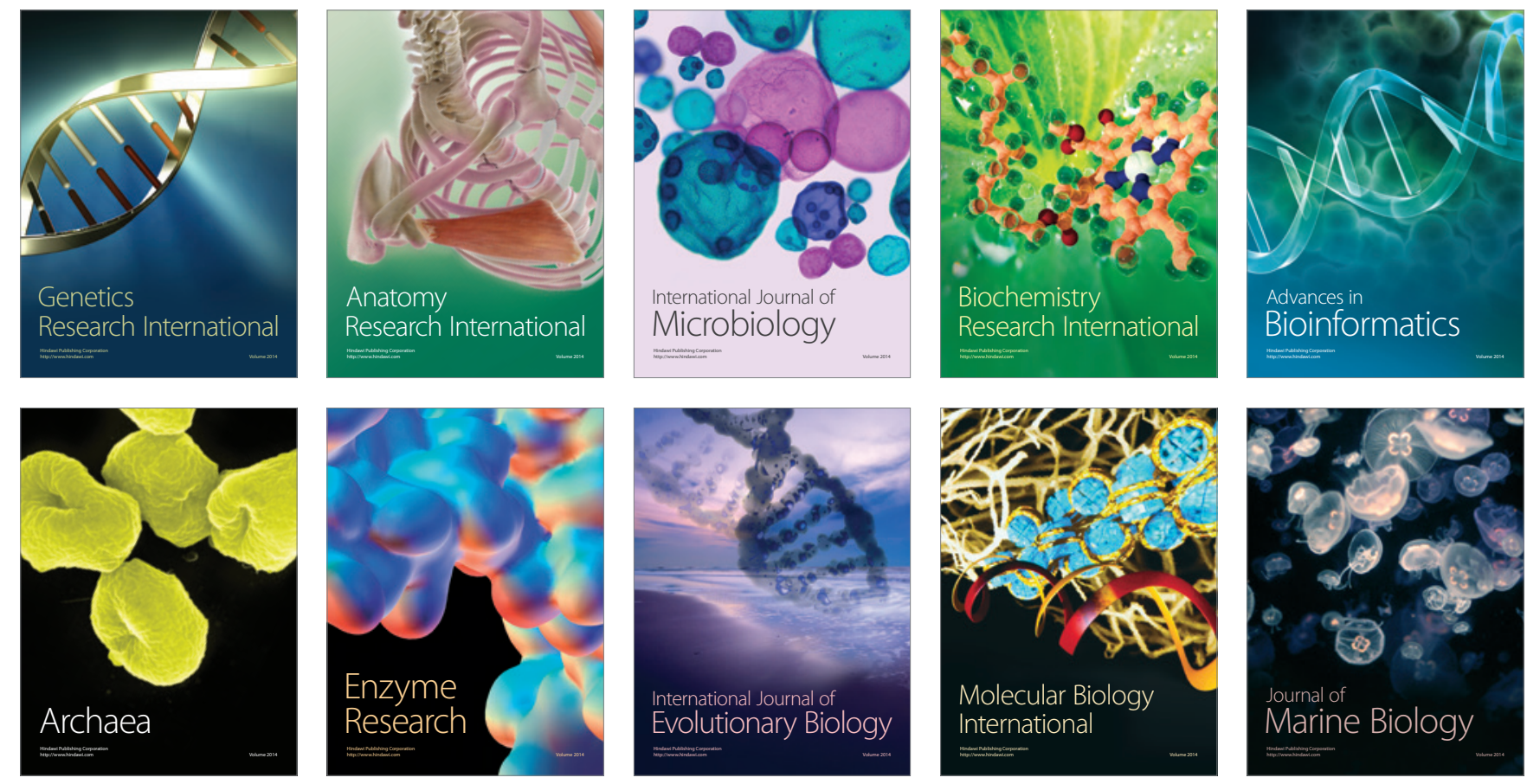